\title{
Seroprevalence of Parenterally and Enterally Transmitted Hepatitis Viruses in a Tertiary Care Hospital of North India - A Two Year Study
}

\author{
Pooja Suri $^{1}$, Deepinder Chhina ${ }^{1}$, Veenu Gupta ${ }^{1}$, Jasdeep Singh ${ }^{1}$, Puneet Chopra ${ }^{2}$, \\ Rajdeep Singh ${ }^{3}$, Rajoo Singh Chhina ${ }^{4}$ \\ Departments of ${ }^{1}$ Microbiology, ${ }^{2}$ Pulmonary and Critical Care, ${ }^{3}$ Preventive \& Social Medicine, ${ }^{4}$ Gastroenterology \\ Dayanand Medical College and Hospital, Ludhiana, Punjab (India)
}

\begin{abstract}
Background \& Objectives : Viral hepatitis is one of the major health concerns in developing countries like India. The present study was undertaken to find out the prevalence of hepatitis B, hepatitis C, hepatitis A and hepatitis E in our area and to compare it with National and International data.

Methods: A total of 34,551 serum samples received over a period of two years (Jan 2010 to Dec 2011) from various wards and intensive care units (ICUs) were processed in the Department of Microbiology for different markers of viral hepatitis. Out of these, 13,570 serum samples were tested for the presence of HBsAg, 13,566 for anti HCV antibodies, 3,871 for anti HAV IgM and 3,584 for anti HEV IgM antibodies by enzyme linked immunosorbent assay (ELISA).

Results : The percentage positivity for hepatitis B, hepatitis C hepatitis A and hepatitis E was 5.95\%, 13.25\%, 6.32\% and $15.43 \%$ respectively in 2010 and $5.62 \%, 14.27 \%, 6.56 \%$ and $23.53 \%$ respectively in 2011 . The overall prevalence of viral hepatitis was more in males as compared to females.

Interpretation \& Conclusion : The prevalence of hepatitis C was more than hepatitis B among the parenterally transmitted viruses while the prevalence of hepatitis $\mathrm{E}$ was more than hepatitis A in enterally transmitted viruses, in both the years making them a major public health problem in our area.
\end{abstract}

Key Words: HAV, HBV, HCV, HEV, viral hepatitis

\section{INTRODUCTION}

Acute viral hepatitis is a systemic infection affecting the liver predominantly. Almost all cases of acute viral hepatitis are caused by one of five viral agents: hepatitis A virus (HAV), hepatitis B virus (HBV), hepatitis C virus (HCV), hepatitis D virus (HDV), and hepatitis E virus (HEV). ${ }^{1}$

These hepatotropic viruses are divided into enteral and parenteral groups on the basis of their mode of transmission. HAV and HEV are enterally transmitted

\section{Corresponding Author :}

Dr. Pooja Suri,

Assistant Professor,

Department of Microbiology,

Dayanand Medical College \& Hospital,

Ludhiana, Punjab, India

Email:poojasuri2003@yahoo.co.in by the fecal-oral route and do not exist in a chronic carrier state. HBV, HCV and HDV are parenterally transmitted, occur in both acute and chronic forms, and when they persist in a chronic carrier state, serve as a reservoir for infection. They have the potential to cause chronic hepatitis, cirrhosis, and hepatocellular carcinoma. ${ }^{2}$

Other transfusion transmitted agents, e.g. hepatitis $G$ virus and Transmitted virus, have been identified but do not cause hepatitis. ${ }^{1}$ Acute viral hepatitis infection is a global public health concern associated with substantial morbidity and mortality. ${ }^{2}$ This is a serious problem in India also and has been reported from all parts of this country. ${ }^{3}$ $\mathrm{HBV}$ is responsible for approximately 300 million cases of chronic infection worldwide. ${ }^{4}$ With a population base of 900 million, the total HBV carrier pool in India is around 43 million. ${ }^{5}$ About 0.04 to $26 \%$ of apparently healthy population in different countries of the world is suffering from chronic HCV infection. India is hyper-endemic for Hepatitis A and E. ${ }^{6}$ Thus, the present study was undertaken to find out the prevalence of $\mathrm{HAV}, \mathrm{HBV}, \mathrm{HCV}$ 
and HEV in our area and compare it with National and International data.

\section{MATERIAL \& METHODS}

A total of 34,551 blood samples $(17,151$ in 2010 \& 17,401 in 2011) were tested for various viral hepatitis markers (HBV-6,704, HCV- 6,875, HAV-1,835 and HEV-1,736 in 2010 \& HBV-6,866, HCV- 6,691, HAV-1,996 and HEV-1,848 in 2011) over a period of two years (from Jan 2010 to Dec 2011). Hepatitis B virus (HBV) infection was diagnosed by detecting HBsAg in sera of suspected cases. Hepatitis $\mathrm{C}$ virus (HCV) infection was established by the presence of anti-HCV antibodies in serum. Similarly, HAV and HEV infections were diagnosed by detecting anti-HAV IgM antibodies and anti-HEV IgM antibodies in serum samples respectively.

From each patient about $5-10 \mathrm{ml}$ of venous blood was collected in a vacutainer without anticoagulant. Serum was separated after centrifugation and then stored at $4^{\circ} \mathrm{C}$ until further processing. These sera were tested for IgM anti-HAV, HBsAg, anti-HCV and IgM anti-HEV. The serological testing for HBsAg and anti-HCV was done by using third generation ELISA kits - Eliscan $\mathrm{HBsAg}$ and Eliscan HCV respectively (Manufactured by RFCL Ltd.), and IgM anti-HAV and IgM anti-HEV was done using General Biologicals Anti-HAV IgM EIA (Mfd by General Biologicals Corp, Taiwan) and HEV IgM (ImmunoVision, USA).

Seasonal trends of hepatitis A and hepatitis E for winter (November - February), summer (March - June) and monsoon (July - October) were also studied.

\section{RESULTS}

The percentage positivity for hepatitis $\mathrm{B}$, hepatitis $\mathrm{C}$ hepatitis A and hepatitis E was 5.95\%, 13.25\%, 6.32\% and $15.43 \%$ respectively in 2010 and $5.62 \%, 14.27 \%$, $6.56 \%$ and $23.53 \%$ respectively in 2011 (Table I). Coinfection of $\mathrm{HBV}$ and $\mathrm{HCV}$ was found in 9 cases in 2010 \& 19 in 2011 and co-infection of HAV and HEV was found in 12 cases in 2010 \& 7 in 2011. Age-wise distribution of all positive viral hepatitis markers is shown in Figures I-IV.

Seasonal variation of hepatitis A and hepatitis E from Jan 2010 to Dec 2011 is depicted in Figures V. The seasonal pattern of HAV/HEV positivity observed during 2010 and 2011 is as follows: HAV- winter $6.2 \% \& 4.3 \%$, summer $5.7 \%$ \& $3.2 \%$ and monsoon $27.2 \% \& 10.9 \%$ respectively; HEV- winter $38.8 \%$ \& $26.1 \%$, summer $16 \%$ $\& 25.2 \%$ and monsoon $12.65 \%$ \& $20.5 \%$ respectively.

\section{DISCUSSION}

Viral hepatitis is a major public health problem throughout the world. This is a serious problem in India also and has been reported from all parts of this country. Moreover, all types of viruses, already characterized and identified as the causative agent of viral hepatitis infect Indian populations . ${ }^{3}$

In our study, we found the prevalence of $\mathrm{HCV}$ infection more than HBV infection in 2010 (13.25\% vs $5.95 \%)$ \& 2011 (14.27\% vs 5.62\%) among the parenterally transmitted viruses tested. This signifies that $\mathrm{HCV}$ is more endemic than HBV in our region. And among the two enterally transmitted viruses, the prevalence of HEV was more than HAV in 2010 (15.53\% vs $6.32 \%) \& 2011(23.53 \%$ vs $6.56 \%)$ in our study. In a study by Subrat $e t a l^{7}$, prevalence of various hepatitis markers was -HAV IgM-14.6\%, HBsAg-12.2\%, HCV $\mathrm{Ab}-3.6 \%$ and $\mathrm{HEV}$ IgM-37.4\%. In a retrospective

Table I

Seropositivity of various markers of viral hepatitis

\begin{tabular}{llllll}
\hline Viral Hepatitis & Diagnostic Criteria & \multicolumn{2}{c}{ Year 2010 } & \multicolumn{2}{c}{ Year 2011 } \\
\cline { 3 - 6 } & & $\begin{array}{l}\text { Number } \\
\text { of } \\
\text { tested }\end{array}$ & Positive (\%) & $\begin{array}{l}\text { Number } \\
\text { of serum } \\
\text { tested }\end{array}$ & Positive (\%) \\
\hline HBV Infection & Positive HBsAg & 6704 & $399(5.95)$ & 6866 & $386(5.62)$ \\
HCV Infection & Positive anti-HCV Ab & 6875 & $911(13.25)$ & 6691 & $955(14.27)$ \\
HAV Infection & Positive anti-HAV IgM & 1835 & $116(6.32)$ & 1996 & $131(6.56)$ \\
HEV Infection & Positive anti-HEV IgM & 1736 & $268(15.43)$ & 1848 & $435(23.53)$ \\
\hline
\end{tabular}




\section{Age- wise distribution of Hepatitis B positive} cases

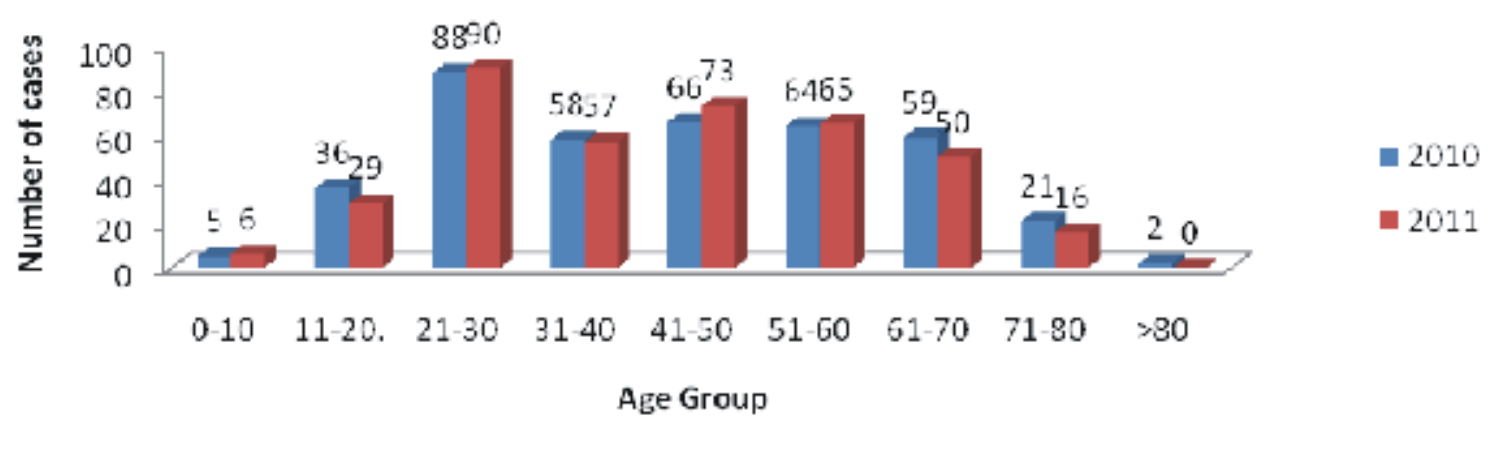

Figure I : Age-wise distribution of hepatitis B positive cases in 2010 \& 2011

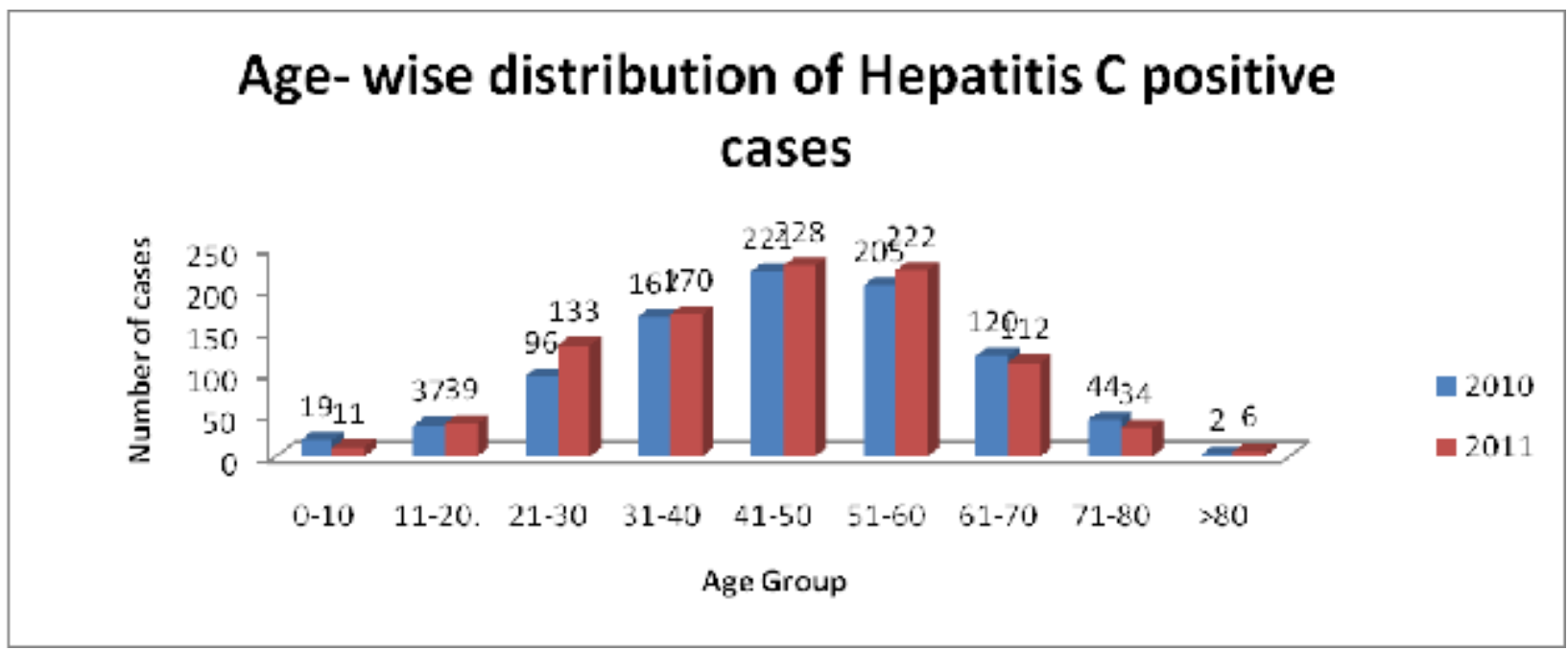

Figure 2: Age-wise distribution of hepatitis C positive cases in 2010 \& 2011

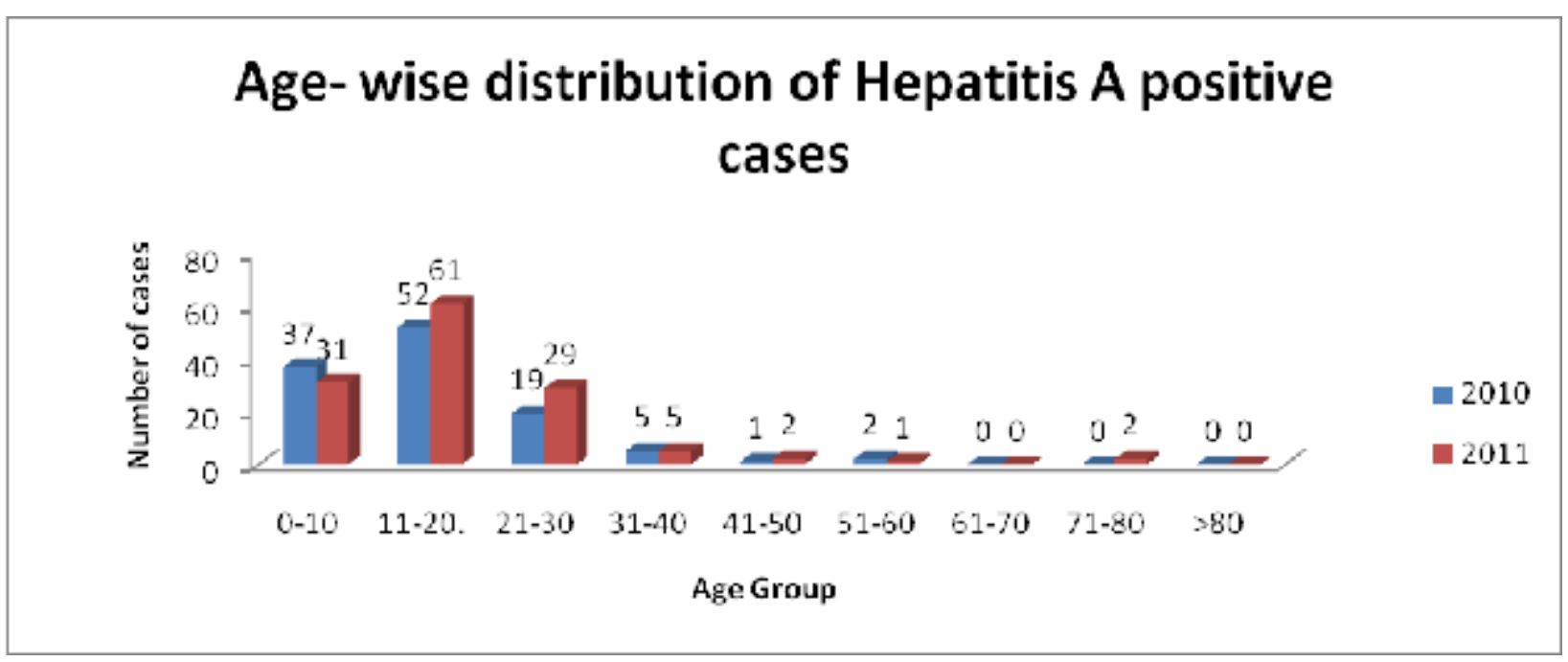

Figure 3 : Age-wise distribution of hepatitis A positive cases in 2010 \& 2011 


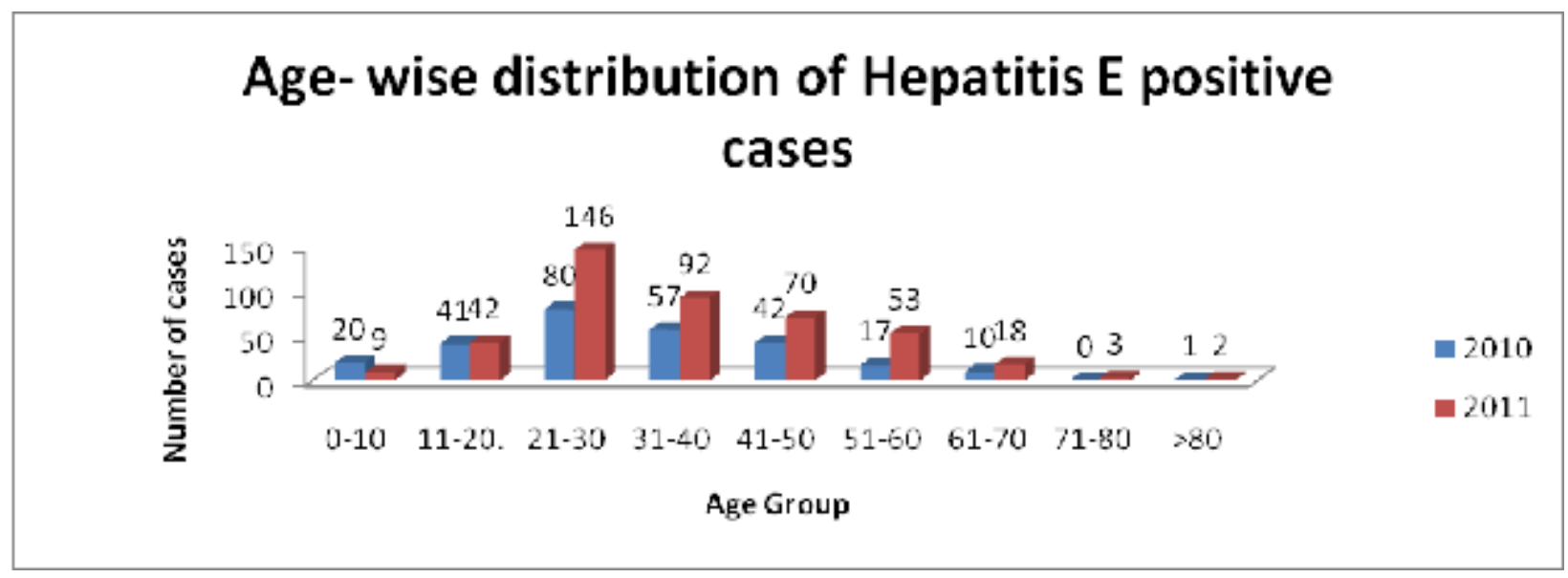

Figure 4 : Age-wise distribution of hepatitis E positive cases in 2010 \& 2011

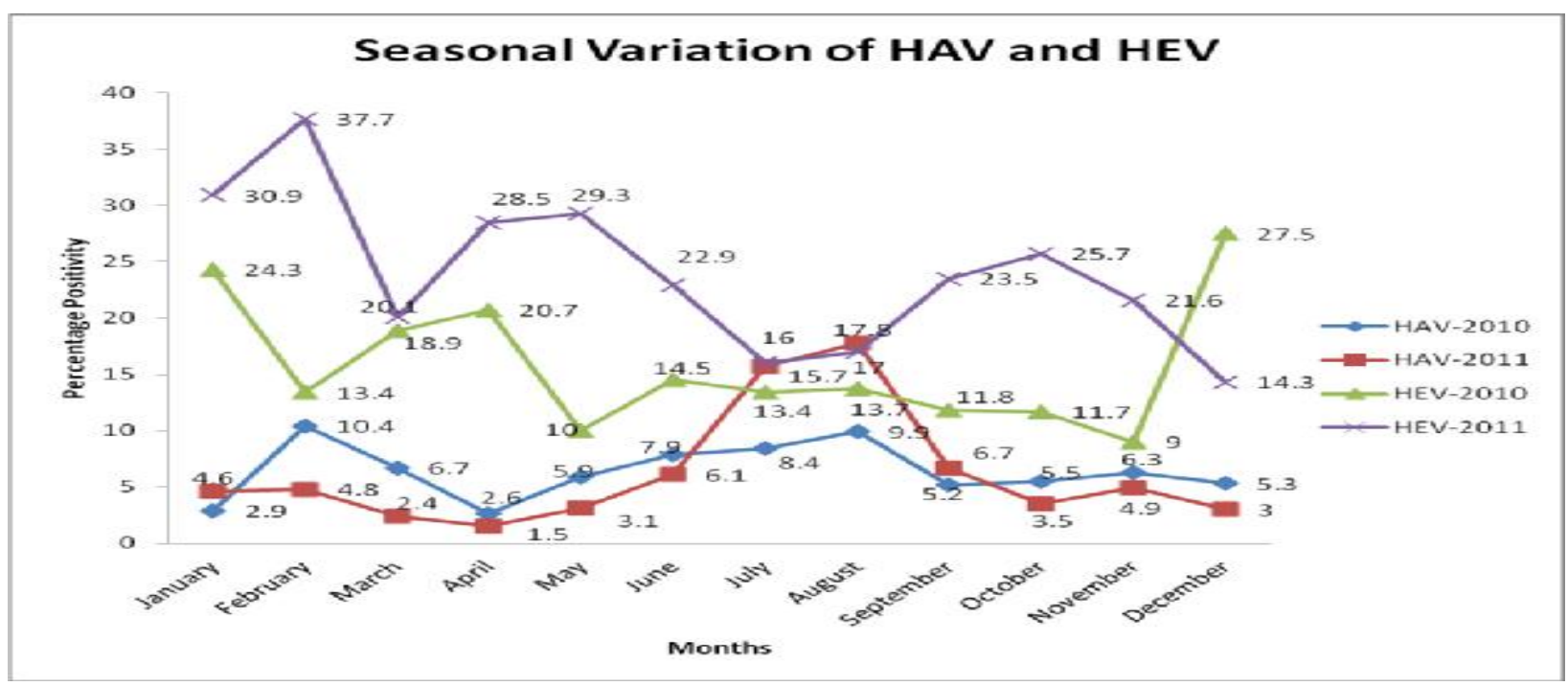

Figure 5: Seasonal variation of HAV \& HEV in 2010 \& 2011

community based study in Alwar the seropositivity for various markers of viral hepatitis was found to be $-32.1 \%$, $1.8 \%, 0 \%, 3.6 \%$, and $7.19 \%$ for hepatitis A, B, C, D and E, respectively. ${ }^{8}$

In a study from a military hospital in south India, hepatitis E was detected in $102(45.4 \%)$, hepatitis A in 74 (33\%), hepatitis B in 28 (12.5\%) and hepatitis C in 2 $(0.9 \%)$ patients. $^{9}$

In an observational population based study by Steinke et al there were 4992 patients identified with viral hepatitis in the study period 1989-1999; 86 were IgM positive anti-hepatitis A, 187 patients were hepatitis B surface antigen (HBsAg) positive, and 469 were anti-hepatitis C (HCV) positive. ${ }^{10}$ While from a separate study from Saudi Arabia, between 2000 and 2007, a total of 14,224 seropositive cases of viral hepatitis were reported to the surveillance system. The average annual incidence of seropositivity per $1,00,000$ served population was highest for HBV (104.6), followed by HCV (78.4), and lowest for HAV (13.6). ${ }^{11}$ In a study from Brazil, the seropositivity for HBsAg was $0.76 \%$ and there was no seropositivity for anti-HCV marker. ${ }^{12}$

The overall incidence of viral hepatitis was more in males as compared to females in all age groups, however there is difference in sub group analysis and male: female 
ratio was about 3:1 in $\mathrm{HBV}$ and $\mathrm{HCV}$ while it was around 2:1 in HAV and HEV in 2010 whereas in year 2011 the ratio was about $3: 1$ in HBV, HCV \& HAV while in HEV it was around 2:1. Similar results were observed in other studies also. ${ }^{8,13}$

Among the parenterally transmitted viruses, it has been observed that highest number of patients $(88 \& 90$ in 2010 \& 2011 respectively) diagnosed with hepatitis B were in the age group of 21-30 years as compared to hepatitis C infection in which majority of the patients (221 \& 228 in 2010 \& 2011 respectively) were in the age group 41-50 years. While among the enterally transmitted viruses, young children are at greater risk of acquiring hepatitis A infections as compared to hepatitis E as most of the patients infected with hepatitis A in our study were in the age group of 11-20 years which is similar to findings of many studies..$^{9,14,15}$

In our study, we observed a peak incidence of hepatitis Ainfection during the monsoons in both the years which is similar to the findings of Singh et $l^{8}$ and Villar et al. ${ }^{16}$ Peak incidence of hepatitis $\mathrm{E}$ was observed during the winters in our study in both the years which is in contrast to the study done by Ippagunta et $a l,{ }^{17}$ who observed maximum positivity in summers.

Seroprevalence studies have shown coinfection of $\mathrm{HBV}$ and $\mathrm{HCV}$, although prevalence may vary from area to area and country to country. Coinfection leads to more aggressive liver disease with the two viruses interacting in poorly defined ways to increase the rate of hepatic fibrosis. ${ }^{18}$ In our study the co-infection of HBV and HCV was found in 9 cases in $2010 \& 19$ in 2011. Devi et al ${ }^{18}$ found co-infection of $\mathrm{HBV}$ and $\mathrm{HCV}$ as $5 \%$ and $4.8 \%$ among the hepatic disorders \& IDU's respectively. In another study by Chakravarti \& Verma, ${ }^{19}$ the HBV and $\mathrm{HCV}$ coinfection was found to be $79.4 \%$ in patients with chronic liver disease while Arora et $\mathrm{l}^{20}$ found no case of coinfection with HBV \& HCV. In our study coinfection of HAV and HEV was found in 12 cases in 2010 \& 7 in 2011 which is in contrast to a study done by Subrat et al, ${ }^{7}$ who found no case of HAV \& HEV coinfection.

The results from our study depict the fact that the prevalence of different markers of viral hepatitis varies not only in different parts of world but also in India. In our study the prevalence of hepatitis $\mathrm{C}$ was more than hepatitis B among the parenterally transmitted viruses while the prevalence of hepatitis $E$ was more than hepatitis A in enterally transmitted viruses, making them a major public health problem in our area. Young people are at greater risk of acquiring hepatitis B infection as compared to hepatitis $\mathrm{C}$ infection among the parenterally transmitting viruses.

To conclude, this study highlights that early screening of clinically diagnosed cases of viral hepatitis is essential step for establishing diagnosis and will allow for the most appropriate use of available resources. Accordingly, the appropriate precautions can be implemented to decrease the prevalence of these emerging infections.

\section{REFERENCES}

1. Waldor MK \& Keusch GT. Cholera and other vibrioses. In: Fauci AS, Braunwald E, Kasper DL, Hauser SL, Longo DN, Janeson JL, Loscalzo J, editors. Harrison's Principles of Internal Medicine: 16th ed. (McGraw Hills, New York) 2008. p.1822.

2. Sulkowski MS, Chaisson RE. Gastrointestinal and hepatobiliary manifestations of human immunodeficiency virus infection. In: Mandell GL, Bennett JE, Dolin R, editors. Principles and Practice of Infectious Diseases. 6th ed. Philadelphia PA: Elsevier; 2005. p. 1426

3. Irshad M, Singh S, Ansari MA, Joshi YK. Viral Hepatitis in India: A Report from Delhi. Global Journal of Health Science 2010;2(2):96-103.

4. Tandon BN, Acharya SK, Tandon A. Epidemiology of hepatitis B virus infection in India. Gut 1996;38(2):S56-S59.

5. Thyagarajan SP, Jayaram S, Mohanavalli B. Prevalence of hepatitis B in general population of India. In: Sarin SK, Singhal AK, editors. Hepatitis B in India: Problems and Prevention. New Delhi: CBS Publishers and Distributors; 1996. p.5-16.

6. Acharya SK, Batra Y, Bhatkal B. Sero epidemiology of hepatitis A virus infection among school children in Delhi; implications for HAV vaccination. J Gastroenterol Hepatol 2003; 18:822-7.

7. Kumar S, Ratho RK, Chawla YK, Chakraborti A. The incidence of sporadic viral hepatitis in North India: a preliminary study. Hepatobiliary Pancreat Dis Int 2007;6:596-9.

8. Singh J, Prakash C, Gupta RS, Bora D, Jain DC, Datta KK. Epidemiology of endemic viral hepatitis in an urban area of India: a retrospective community study in Alwar. Bull World Health Organ 1997;75(5):463-8.

9. Nandi B, Hadimani P, Arunachalam R, Ganjoo RK, Spectrum of Acute Viral Hepatitis in Southern India. MJAFI 2009;65(1): 7-9.

10. Steinke DT, Weston TL, Morris AD, MacDonald TM, Dillon JF. Epidemiology and economic burden of viral hepatitis: an observational population based study. Gut 2002;50(1): 100-5.

11. Memish ZA, Knawy BA, El-Saed A. Incidence trends of viral hepatitis A, B, and C seropositivity over eight years of surveillance in Saudi Arabia. Int J Infect Dis 2010;14:e115-20.

12. Livramento A, Cordova CM, Spada C, Treitinger A. Seroprevalence of hepatitis B and C infection markers among 
children and adolescents in the southern Brazilian region. Rev Inst Med Trop Sao Paulo 2011;53(1):13-7

13. Mishra B, Srinivasa H, Muralidharan S, Charles S, Macaden RS. A hospital based study of Hepatitis E by serology. Indian J Med Microbiol 2003;21:115-7.

14. Malathi S, Mohanavalli B. Clinical and viral marker pattern of acute sporadic hepatitis in children in Madras, South India. J Trop Pediatr 1998;44:275-8

15. Kaur R, Gur R, Berry N, Kar P. Etiology of endemic viral hepatitis in urban North India. Southeast Asian J Trop Med Public Health 2002;33:845-8.

16. Villar LM, De-Paula VS, Gaspar AM. Seasonal variation of hepatitis A virus infection in the city of Rio de Janeiro, Brazil. Rev Inst Med Trop Sao Paulo 2002;44(5):289-92.
17. Ippagunta SK, Naik S, Sharma B, Aggarwal R. Presence of hepatitis $\mathrm{E}$ virus in sewage in Northern India: frequency and seasonal pattern. J Med Virol 2007;79(12):1827-31.

18. Devi KS, Singh NB, Mara J, Singh TB, Singh YM. Seroprevalence of hepatitis $\mathrm{B}$ virus and hepatitis $\mathrm{C}$ virus among hepatic disorders and injecting drug users in manipur - A preliminary report. Indian J Med Microbiol 2004;22:136-7.

19. Chakravarti A, Verma V. Prevalence of hepatitis C and B viral markers in patients with chronic liver disease: A study from Northern India. Indian J Med Microbiol 2005;23:273-4.

20. Arora DR, Sehgal R, Gupta N, Yadav A, Mishra N, Siwach SB. Prevalence of parenterally transmitted hepatitis viruses in clinically diagnosed cases of hepatitis Indian J Med Microbiol 2005;23(1):44-7. 


\section{PDF created with pdfFactory Pro trial version www.pdffactory.com}

